\title{
Prevention and Management of Staple Line Leaks after Laparoscopic Sleeve Gastrectomy
}

\author{
Sotirios Botaitis*, Athanasia Mitsala, Sempachedin Perente, Constantinos Simopoulos
}

Second Department of Surgery, Democritus University of Thrace School of Medicine, Alexandroupolis, Greece

*Corresponding author: Sotirios Botaitis, M.D, Democritus University of Thrace School of Medicine, Dragana Alexandroupolis 68100, Greece, Tel: +302551351011/ Fax: +302551030412; E-mail: smpotait@med.duth.gr

\begin{abstract}
:
Laparoscopic Sleeve Gastrectomy (LSG) is gaining ground as a bariatric procedure with proven efficacy on weight loss and obesity-related comorbidities. Compared to other bariatric procedures, its complications can be even more severe. Gastric leak is estimated to be the most serious complication of this procedure due to difficult healing processes not to mention the fact that it may also be responsible for local or general severe septic complications. Staple line dehiscence and subsequent leaks following sleeve gastrectomy are not very frequent but are a difficult complication that can also become chronic. Various options have been suggested but no definitive has been established.

The management of patients who develop leakages requires a multidisciplinary team. Choosing the proper approach depends on the clinical condition of the patient and the onset time of leak. Main aim of this paper is to provide an overview of the pathogenic and promoting factors of staple line leak following LSG on the basis of recent literature review and to report the evidence based preventive measures and treatment solutions of this life-threatening complication.
\end{abstract}

Keywords: Laparocopy; Sleeve gastrectomy; Leakage; Fistula; Morbid obesity

\section{Introduction}

Laparoscopic Sleeve Gastrectomy (LSG) has become an important therapeutic option in the treatment of morbid obesity during recent years. It has demonstrated to be effective for achieving weight loss, comorbidity resolution and a better quality of life in obese patients. The reduction in mortality and morbidity rates with this bariatric procedure are due to the highly significant improvement in those diseases that are caused or worsened by obesity.

LSG is currently gaining ground due to its efficacy in terms of combined restrictive and hormonal effects ${ }^{[1]}$. The new stomach pouch holds a considerably smaller volume than the normal stomach and helps to significantly reduce the amount of food (and thus calories) that can be consumed. It restricts the stomach's size to induce satiety and resects fundal ghrelin-producing cells to decrease appetite ${ }^{[2,3]}$. Ghrelin is an orexigenic (appetite-stimulating) peptide hormone whose mechanism in weight loss is unclear. Concentrations rise before meals, stimulating the appetite, and decrease shortly after food ingestion. Two of the well-studied gut-derived peptides, glucagon-like peptide-1 (GLP-1) and peptide YY (PYY), are secreted from L cells in the distal small bowel in response to nutrient intake ${ }^{[4]}$. Multiple studies have shown that obese individuals have decreased basal and postprandial PYY levels as well as a decreased postprandial GLP-1 response as compared to lean individuals ${ }^{[5]}$. Patients after LSG experience a more expedited nutrient trans- port into the distal ileum, eliciting an augmented postprandial secretion of GLP-1 and PYY[6]. The markedly reduced ghrelin levels in addition to increased PYY levels after LSG, are associated with greater appetite suppression and excess weight loss ${ }^{[7]}$. The continuity of the stomach and the outlet valve (pylorus) remain intact to preserve the functions of the stomach while reducing the volume it is able to hold. In addition to avoiding foreign bodies, such as the laparoscopic adjustable gastric band, the other advantage that LSG carries over other bariatric procedures, such as Roux-en-Y gastric bypass (RYGB) or duodenal switch (DS), is the elimination of dumping syndrome ${ }^{[8]}$.

The fact that this technique has erroneously been considered simple and easy has led to its adoption by a large number of surgeons. Compared to gastric bypass and biliopancreatic diversion, its complications can be even more severe ${ }^{[9]}$. Staple

Received date: May 17, 2018

Accepted date: June 18, 2018

Published date: June 22, 2018

Citation: Botaitis, S., et al. Prevention and Management of Staple Line Leaks after Laparoscopic Sleeve Gastrectomy. (2018) J Anesth Surg 5(1): 95- 102.

Copy Rights: (C) 2018 Botaitis, S. This is an Open access article distributed under the terms of Creative Commons Attribution 4.0 International License. 
Citation: Botaitis, S., et al. Prevention and Management of Staple Line Leaks after Laparoscopic Sleeve Gastrectomy. (2018) J Anesth Surg 5(1): 95- 102.

line leaks, bleeding, strictures and postoperative increased rate of gastroesophageal reflux disease (GERD) (described as either de novo or as being caused by aggravation of preexisting symptoms) are the commonly reported complications following LSG. Gastric leak is estimated to be the most serious complication of this procedure due to difficult healing processes not to mention the fact that it may also be responsible for local or general severe septic complications ${ }^{[10]}$. This dreaded complication, although appearing in a low percentage of patients, is associated with high morbidity and mortality rates, prolonged hospital stay and may put the patient's life at risk ${ }^{[11]}$. The leak rate has a reported mean incidence of $2.1 \%(1.1-5.3 \%)^{[12]}$.

Main aim of this paper is to provide an overview of the pathogenic and promoting factors of staple line leak following LSG on the basis of recent literature review and to report the evidence based preventive measures and treatment solutions of this life-threatening complication ${ }^{[9,15-18,22,35]}$.

\section{Definition of Leak}

According to the United Kingdom Surgical Infection Study Group, a gastric leakage was defined as "the leak of luminal contents from a surgical join between two hollow viscera". It can also be an effluent of gastrointestinal contents through a suture line, which may collect near the anastomosis, or exit through the wall or the drain ${ }^{[13]}$.

Leakage can be classified based either on the time of onset, clinical presentation, site of leak, radiological appearance, or mixed factors. According to the time of onset, Csendes et $\mathrm{al}^{[14]}$ classified leakage as early when appearing within the first four postoperative days, intermediate when appearing in postoperative days 5-9 and late when occurring in or after the tenth postoperative day. By clinical relevance and extent of dissemination, type I or subclinical leakage was defined as well localized leak without dissemination into the pleural or abdominal cavity, or inducement of systemic clinical manifestations, and usually they are easy to treat medically. Type II is leaks with dissemination into pleural or abdominal cavity, or the drains with consequent severe and systemic clinical manifestations.

Welsch et $\mathrm{al}^{[15]}$ defined leaks as type A, B and $\mathrm{C}$ based on both clinical and radiological findings. Type A leaks are micro-perforations without clinical or radiographic evidence of leak, while type B are leaks detected by radiological studies but without any clinical finding, and finally, type $\mathrm{C}$ are leaks presenting with both radiological and clinical evidence.

The majority of staple line leaks associated with sleeve gastrectomy appears in the proximal third of the stomach, immediately below the level of gastroesophageal junction, followed in frequency by leaks that appear as disruption of the staple line in the distal third of the stomach. The following table is based on recent literature review ${ }^{[16-23]}$ (Table 1).
Table 1: Location of the staple line leak at the stomach according to frequency as found by different series n (\%).

\begin{tabular}{|l|l|l|l|c|c|}
\hline & $\begin{array}{l}\text { Number of } \\
\text { patients }\end{array}$ & $\begin{array}{l}\text { Prox- } \\
\text { imal } \\
\text { third }\end{array}$ & $\begin{array}{l}\text { Mid- } \\
\text { third }\end{array}$ & $\begin{array}{l}\text { Distal } \\
\text { third }\end{array}$ & $\begin{array}{l}\text { Other sites } \\
\text { or not } \\
\text { located }\end{array}$ \\
\hline $\begin{array}{l}\text { Mui et al. } \\
\text { [16] }\end{array}$ & $\begin{array}{l}70 \text { patients, } 1 \\
\text { leak (1.42\%) }\end{array}$ & 100 & 0 & 0 & 0 \\
\hline $\begin{array}{l}\text { Burgos et } \\
\text { al. }{ }^{[1]}\end{array}$ & $\begin{array}{l}214 \text { patients, } 7 \\
\text { leaks (3.27\%) }\end{array}$ & 85.7 & 14.3 & 0 & 0 \\
\hline $\begin{array}{l}\text { Csendes } \\
\text { et al. }{ }^{[1]}\end{array}$ & $\begin{array}{l}334 \text { patients, } 16 \\
\text { leaks (4.79\%) }\end{array}$ & 87.5 & 12.5 & 0 & 0 \\
\hline $\begin{array}{l}\text { Ser et al. } \\
\text { [19] }\end{array}$ & $\begin{array}{l}118 \text { patients, } 4 \\
\text { leaks (3.38\%) }\end{array}$ & 100 & 0 & 0 & 0 \\
\hline $\begin{array}{l}\text { Lacy et } \\
\text { al. }{ }^{[20]}\end{array}$ & $\begin{array}{l}294 \text { patients, } 11 \\
\text { leaks (3.74\%) }\end{array}$ & 100 & 0 & 0 & 0 \\
\hline $\begin{array}{l}\text { Jurowich } \\
\text { et al. }{ }^{[21]}\end{array}$ & $\begin{array}{l}45 \text { patients, } 4 \\
\text { leaks (8.88\%) }\end{array}$ & 75 & 25 & 0 & 0 \\
\hline $\begin{array}{l}\text { Sakran et } \\
\text { al. }{ }^{[2]}\end{array}$ & $\begin{array}{l}2834 \text { patients, } \\
44 \text { leaks }\end{array}$ & 75 & 6.8 & 6.8 & 11.3 \\
\hline $\begin{array}{l}\text { (1.55\%) } \\
\text { Moon et } \\
\text { al. }{ }^{[23]}\end{array}$ & $\begin{array}{l}539 \text { patients, } 15 \\
\text { leaks (2.78\%) }\end{array}$ & 100 & 0 & 0 & 0 \\
\hline
\end{tabular}

\section{Causes}

Pathogenesis of leakage after LSG can be attributed to mechanical or ischemic causes. According to Baker et al. ${ }^{[24]}$, stapler misfiring or direct tissue injuries are categorized as "mechanical-tissular" causes and usually appear within 2 days of surgery (early leak), compared to the "ischemic" causes that usually appear on day 5 - 6 post operatively (post op) (intermediate leak).

In a multicenter experience with 2834 patients, Sakran et al ${ }^{[22]}$ concluded that leaks following LSG were related to improper vascularization due to an aggressive dissection especially of the posterior attachments of the upper sleeve, thermal injuries to the gastric tube by ultrasonic devices (Harmonic, Ligasure), stapler devices misfiring and stapling of the orogastric tube. Patients with distal stenosis are more likely to have proximal leaks as narrowing of the gastric incisura results in a partial obstruction leading to a high-pressure intraluminal system, gastric emptying impairment and decreased compliance of the gastric tube ${ }^{[18,25]}$. In addition, gastric leaks are secondary to an impaired normal acute healing process. Local risk factors include impaired suture line healing, poor blood flow, infection and poor oxygenation with subsequent ischemia ${ }^{[9]}$.

Furthermore, for revisional sleeve gastrectomy, as either LSG after gastric band or re-sleeve, the risk of leakage is higher due to dense adhesions, scaring and ischemic tissues ${ }^{[26]}$. According to a recent multicentric observational study involving 5400 patients with LSG as primary procedure ${ }^{[27]}$, there is reported an association of male gender and BMI between 50 and 59.9 $\mathrm{kg} / \mathrm{m}^{2}$ with significantly higher leakage rate $(2.5$ vs. $1.6 \% ; \mathrm{p}=$ $0.02: \mathrm{p}<0.01$ respectively). The presence of at least one comorbid condition did not increase the risk of leak in that study ( 2 vs. $1.3 \% ; \mathrm{p}=0.24)$. Nevertheless, a significant association was demonstrated for a concomitant sleep apnea (2.6 vs. $1.8 \%$; $\mathrm{p}=$ $0.04)$ when analyzing each comorbidity separately. The highest proportion of leaks along the staple line was demonstrated for procedures with conversion to open approach $(14.6 \% ; \mathrm{p}<0.01)$. 


\section{Prevention}

Risks of leak and subsequent fistula after sleeve gastrectomy present significant concerns in clinical practice. Awareness of the predisposing factors and technical tips may decrease the incidence of this complication. The surgical technique is among the major determinants of the morbidity of this bariatric procedure. The surgeon must be careful and do gentle handling of tissues with good hemostasis. Avoid the damaging of tissues when using electrocautery equipment ${ }^{[18]}$.

Prevention of distal stenosis: Several publications ${ }^{[28,29]}$ have advocated the importance of the learning curve for different bariatric procedures in order to diminish the postoperative complication rate. It is important to select the appropriate stapler load to minimize the issue of stapler malformation or failure. Appropriate staple height depends on gastric tissue thickness, varies according to the patient's gender, BMI, and stomach site, and also tends to decrease from distal to proximal. Under-sizing the staple cartridge increases the risk of inadequate staple formation or can lead to excessive tissue compression, which exceeds the tissue's tensile strength, leading to tearing and perforation ${ }^{[28]}$. Proper compression time is also necessaryin order to washout the fluids from the tissues, especially in thick tissue. Usually, waiting at least 15 seconds before firing helps to optimize this concept and allows adequate pre-cut compression time ${ }^{[24]}$.

Sleeve gastrectomy is not a simple procedure and owing to the fact that it is irreversible, surgeons should strive to minimize the risk of creating strictures at the incisura angularis by avoiding stapling too close or tight to the bougie. In addition, it is essential to avoid stapling near the esophagus at the angle of His, as most leaks occur near or distal gastroesophageal (GE) junction $^{[10]}$.

Most operators reinforce the staple line in order to decrease bleeding and leaks, and choices may vary from suturing to buttressing. Several studies concluded that reinforcement with oversewing decreases the leakage rate ${ }^{[31]}$. Some authors ${ }^{[32-34]}$ recommend the use of PSD (Peri Strips Dry, a bovine pericardium with collagen matrix) in order to protect the staple line, while others agree that reinforcement decreases the complication rate in term of bleeding but not in term of leak ${ }^{[35]}$. Consten et $\mathrm{al}^{[36]} \mathrm{de}-$ scribed the use of absorbable polymer membrane (Seamguard, Gore) to strengthen the suture line. Márquez et al ${ }^{[9]}$ protect the staple line with a continuous sero-serous suture that inverts the staples, controls bleeding and reduces the number of leaks, without increasing the cost of the procedure. The use of reinforcement of the staple line along with increased surgeon experience could be equally responsible for low leak rate.

Fibrin sealants (Tissucol, Vivostat) were also addressed in several studies with good impact in term of preventing staple line leakage ${ }^{[37,38]}$. These substances polymerize on contact with a tissue surface via an exothermic reaction. This polymerization process not only joins the tissues, but also acts as a sealant to prevent leaks.

Based on what we mentioned previously concerning the impact of increased intraluminal pressure on the gastric leak formation $^{[22]}$, Márquez et al. leave the nasogastric tube in place for $24 \mathrm{~h}$ postoperatively to decrease intraluminal pressure ${ }^{[9]}$. Pyloromyotomy has reduced the gastric pressure to an extent that was adequate to relieve heart burn and other symptoms of GERD, but only in the immediate postoperative period. This procedure was not sustained for a long period and it was not enough to prevent staple line leak, despite the fact that definitely high intraluminal pressure played a role in the progress of leak $^{[38]}$.

In the Expert consensus statement in $2012,87 \%$ of the panelists agreed that it was essential to use a bougie to size the sleeve and the optimal size of the bougie should be between 32 to $36 \mathrm{Fr}^{[30]}$. Using a bougie of $<32 \mathrm{Fr}$ may increase the postoperative strictures, while a bougie of $>36 \mathrm{Fr}$ may bring about limited weight loss effects due to possible dilatation of the sleeve.

The intraoperative detection of a technically induced staple line defect can be treated with prompt closure. For identifying staple line leak during LSG, intraoperative testing, including methylene blue and/or air leak tests or intraoperative endoscopy are usually performed. But, the fact of the matter is that a negative intraoperative methylene blue test cannot exclude the development of a postoperative leak ${ }^{[22]}$. The use of closed suction drain near the staple line, despite that it is performed by the majority of surgeons, may not detect leak, and may not be helpful also in the drainage of the collection ${ }^{[35]}$.

Another important factor that has been implicated in staple line leaks is poor tissue perfusion leading to poor tissue healing and staple line disruption. Recent technological advances in fluorescence imaging allow surgeons the ability to evaluate tissue perfusion in real-time. After completion of the sleeve gastrectomy, indocyanine green (ICG) can be injected intravenously, and within 30 seconds, tissue perfusion can be observed using a fluorescence imaging system (Pinpoint $\AA$, Novadaq Technologies Inc., Bonita Springs, Florida, United States). Tissue with good perfusion will uptake the ICG and will be shown as green fluorescence. The brighter the fluorescence, the better the tissue perfusion is. This technology is particularly applicable in complex revisional cases where tissue dissection can lead to development of tissue ischemia. Ischemic tissue left undetected can lead to perforation or staple line leaks. If relative ischemia or poor tissue perfusion is detected along the staple line, some maneuvers can be performed to minimize the risk for development of postoperative leaks such as oversewing of the staple line, buttressing the staple line with an omental patch, or using a fibrin sealant ${ }^{[40]}$.

The cornerstones in the revisional bariatric surgery include clear identification of the existing anatomy necessitating extensive dissection and adhesiolysis, taking in consideration the stomach wall thickness due to fibrosis or edema, pushing the surgeon to appropriately choose the size of stapler's height (usually $4.5 \mathrm{~mm}$ ), oversewing of the gastric tube at the level of the staple line, leak test and gastrostomy tube ${ }^{[41]}$.

High leakage rate is particularly prevalent in revisional cases whereby the gastric tissue can be thick and inflamed. For example, conversion of laparoscopic adjustable gastric banding (LAGB) to LSG can lead to a higher staple line leak rate than primary sleeve gastrectomy cases. Staple line leaks normally occur along the gastric staple line in the region of the previous gastric banding. Based on the increased incidence of leakage in the revision surgeries, some authors advocate two steps procedure, gastric band removal followed by the sleeve with a delay between 6 to 12 weeks $^{[42,43]}$.

\section{Clinical Presentation and Diagnostic Workup}

The clinical presentation of gastric leak can vary widely between completely asymptomatic patients to the signs and 
Citation: Botaitis, S., et al. Prevention and Management of Staple Line Leaks after Laparoscopic Sleeve Gastrectomy. (2018) J Anesth Surg 5(1): 95- 102.

symptoms of a septic shock including fever, abdominal pain, peritonitis, leukocytosis, tachycardia and hypotension ${ }^{[15]}$. High clinical suspicion is important as early recognition provides optimal management. Unexplained fever and tachycardia following LSG should push the surgeon to perform further radiological investigations to detect the presence of leak. According to Csendes et $\mathrm{al}^{[18]}$, fever is the most important clinical factor in the diagnosis of gastric leak post sleeve gastrectomy. Others agree that tachycardia is the earliest and most important clinical finding indicating the presence of staple line leak ${ }^{[17]}$. In general, symptomatology such as abdominal pain, vomiting, fever and tachypnea should raise the index of suspicion for diagnosis of this potentially lethal complication.

Early leaks often present with sudden abdominal pain, accompanied with fever and tachycardia in most cases, while late leaks tend to present with insidious abdominal pain usually associated with fever ${ }^{[35]}$

Laboratory studies, including CBCD (Complete blood count with differential), CRP (C-reactive protein), are neither sensitive nor specific and they rarely contribute to make a diagnosis $^{[22]}$. The complete assessment of a chest X-raymay help rule out other causes of tachycardia such as pneumonia, pulmonary embolism, or pleural effusion. An intraoperative methylene blue test is also recommended, even though this method is useful only when results are positive, as we mentioned previously.

An upper gastrointestinal transit test is frequently used postoperatively to assess the presence of staple line leaks. This fluoroscopic test is used to identify the magnitude and the level of the leak, abnormal gastric emptying and presence of stenosis or total obstruction ${ }^{[17,35]}$. On the whole, a water-soluble contrast material is used (Gastrografin) if there is risk of leak, although some authors prefer a diluted barium suspension due to its increased sensitivity to detect small staple line leaks ${ }^{[44,45]}$. The gastrografin swallow test is usually performed 24-72 hours postoperatively. The fact of the test being negative three days after surgery could give rise to a false sense of security since most leaks appear after the third day ${ }^{[1]}$. In patients with clinical presentation of a suspected leak after sleeve gastrectomy, UGI contrast studies have a low sensitivity $(0 \%-25 \%)$, though higher specificity $(90 \%-95 \%)$. In case of doubt or with the purpose of increasing sensitivity, most studies recommend obtaining a computed tomography $(\mathrm{CT})^{[46-48]}$.

$\mathrm{CT}$ of the abdomen with oral and intravenous contrast material is performed for the diagnosis of a staple line leak in patients who show signs and symptoms suggestive of a leak. This method is useful to identify the postoperative normal anatomy and the presence of complications after LSG. The presence of abdominal collection or flee fluid, extravasation of contrast into the abdominal cavity or the drain tube and persistent pneumoperitoneum are diagnostic findings of a staple line leak or fistula[49]. CT is considered to be the best non-invasive modality for detection and confirmation of a gastric leak ${ }^{[18,35]}$. According to Sakran et $\mathrm{al}^{[22]}$, CT had the highest detection rate of gastric leaks in up to $86 \%$ of patients. CT results are also influenced by patient factors, the experience of the radiologist, the size of the leak, and the contrast material used. As a matter of fact, the sensitivity of CT scan declines with the degree of obesity. The abdominal girth along with the total weight of the patient and the artifacts related to large body dimensions may reduce the quality of the images ${ }^{[50]}$.

\section{Management}

The correct treatment of fistulas and leaks that appear after sleeve gastrectomy imposes a lot of difficulties in the adoption of a standard algorithm. Management mainly depends on the condition of the patient and the skills and experience of the surgeon. Non-operative treatment is the preferred approach in hemodynamically stable patients. Even so, gastric leaks tend to become persistent and progress to chronic fistulas due to the unique features of LSG (elevated intraluminal pressure, intact pylorus, with or without strictures) despite non-operative treatment ${ }^{[9]}$. A leak may progress to a fistula after 12 weeks ${ }^{[30]}$. Patients presenting with hemodynamic instability require prompt surgical intervention by laparoscopic or open means for washout and drainage or also debridement and suturing of the orifice ${ }^{[17]}$.

Some authors support primary repair of the defect and immediate surgical intervention with washout drainage and suturein patients with early leaks due to the fact that the surrounding tissues are in an early stage of inflammation ${ }^{[17]}$. While the adoption of a more conservative approach for intermediate and late leaks in clinically stable patients is more reasonable with adequate hydration, proton pump inhibitors, nil peros, nutritional support, percutaneous drainage of any collection and broad spectrum antibiotic therapy, with a follow up weekly by upper gastrointestinal series to ensure healing. Whenever there is any concern about healing, more invasive approaches may be considered.

Most patients who underwent suturing for their fistula failed to close directly due either to persistence of the leak (the defect cannot be identified clearly) or failure of the suture (surrounding tissues are inflamed and friable), especially after the third day post $\mathrm{op}^{[18]}$. A simultaneous endoscopic intervention and insertion of a guide wire (rendez-vous) is used from the stomach lumen so that the surgeon can identify the defect in order to suture $\mathrm{it}^{[51]}$.

If the leak does not heal after several weeks (usually 2 weeks), endoscopic management of gastric leakage is required according to the studies ${ }^{[52]}$. Non-surgical approaches consist of endoscopic clips, sealants, and self-expanding stents.

Over the scope clips (OTSC) have more promising results, but they are limited for very small mucosal defects and microperforations ${ }^{[53]}$. Sealant materials (fibrin glue, cyanoacrylates) are also used for the treatment of leaks. Fibrin glue acts by dual effect, as a plug directly occluding the defect and as a fibroblast promoter to enhance wound healing. It is also absorbed after 4 weeks and is replaced by connective scar tissue.

Self-expandable stents produce occlusions to stop or bypass leaks. Its use gained a widespread in the treatment of proximal and middle gastric leak due to the advantage of the ability to resume per os feeding and discharge the patient home ${ }^{[54]}$. A multicenter study involving 15 patients, with prior gastric bypasses and LSG, reported a 93\% success rate in gastrobronchial fistula closures ${ }^{[55]}$. Tolerance to stents is variable. Nausea, vomiting, early satiety and epigastric discomfort are the most common symptoms after their placement and tend to disappear within the initial days. Adhesions, mucosal tears and bleeding can appear after the procedure. Stent migration is a main concern following their placement. This occurs in up to a third of the patients with self-expandable stents. Afterwards, the stent should be relocated, removed or passed per rectum without incidence ${ }^{[56]}$.

Nguyen et al. used self-expanding stents with a success rate of $100 \%{ }^{[52]}$. The gastric leaks post LSG usually requires 
more than 6 weeks healing. At the same time, keeping the stents for long periods risks to damage the underlying mucosa (especially the uncovered stents). Ideally, most authors agree that 6 to 8 weeks is the optimal removal time ${ }^{[22,52]}$.

Bège et al. suggested a complete endoscopic approach: washout and drainage using natural orifices transluminal endoscopic surgery (NOTES); Diversion uses a stent; Closure with glue or clips ${ }^{[57]}$.

Patients who do not respond to any of the previously mentioned non- operative treatment are candidates for three types of reintervention. First, conversion to gastric bypass, second to en-bloc resection of the fistula with proximal gastrectomy and conversion to Roux-En-Y, and, third, total gastrectomy with esophagojejunal anastomosis ${ }^{[58]}$. In Table 2 summarize the management of staple line leaks after laparoscopic sleeve gastectomy.

Table 2: Management of Staple Line Leaks after Laparoscopic Sleeve Gastrectomy.

\begin{tabular}{|c|c|}
\hline \multicolumn{2}{|c|}{$\begin{array}{l}\text { Management of Staple Line Leaks after Laparoscopic Sleeve } \\
\text { Gastrectomy }\end{array}$} \\
\hline $\begin{array}{l}\text { Hemodynamically stable } \\
\text { patients }\end{array}$ & $\begin{array}{l}\text { Hemodynamically instability or } \\
\text { patients who do not respond to } \\
\text { endoscopic modalities }\end{array}$ \\
\hline $\begin{array}{l}\text { Non operative treatment with } \\
\text { closure techniques }\end{array}$ & Surgical intervention \\
\hline Endoclips, over the scope clips & Conversion to gastric bypass \\
\hline $\begin{array}{l}\text { Sealant materials including } \\
\text { fibrin glue and cyanoacrylates }\end{array}$ & $\begin{array}{l}\text { Conversion to Rou En-Y with a } \\
\text { jejuna limb over sewn over the } \\
\text { fistula }\end{array}$ \\
\hline Endoprosthesis (stents) & $\begin{array}{l}\text { Total gastectomy with esojejunal } \\
\text { anastomosis }\end{array}$ \\
\hline
\end{tabular}

\section{Conclusion}

LSG is gaining wide popularity for the surgical management of morbid obesity. Despite the fact that this technique has erroneously been considered simple, there are several technical tips that surgeons should follow in order to minimize the risk of postoperative complications.

The presence of leakage determines a serious and life-threatening complication of this bariatric procedure, which is associated with long hospitalization time and high morbidity and mortality rates. Awareness of the predisposing factors, which are either technically related or patient related, may decrease the leak rate. In view of the absence of a clear approach and guidelines for the management of the leakage along the staple line after sleeve gastrectomy, the treatment is actually variable and mainly depends on the condition of the patients and the skills and experience of the surgeon. Endoscopy can plays a crucial role in the management of post bariatric complications, but needs a close cooperation between endoscopists and surgeon. Endoscopic techniques for the management of after bariatric surgery leakage could provide a safe and effective alternative to reintervention surgery. Also, most of the data demonstrates that the appropriate management of this dreaded complication should be planned taking into consideration the clinical condition of the patient, time of diagnosis and finally the location of the leak. In consideration of the small number of leakages, fur- ther studies, based on larger series of morbidly obese patients, are needed in order to validate the treatment solutions of this serious complication.

Conflict of Interest: no conflict of interest to report.

\section{References}

1. Del Genio, G., Tolone, S., Limongelli, P., et al. Sleeve gastrectomy and development of "de novo" gastroesophageal reflux. (2014) Obes Surg 24(1): 71-77.

PubMed | CrossRef | Others

2. Serra, C., Pérez, N., Bou, R., et al. Gastrectomía tubular laparoscópica. Una operaciónbariátrica con diferentesindicaciones. (2006) Cir Esp 75(5): 289-292.

PubMed | CrossRef $\mid$ Others

3. Marceau, P., Cabanac, M., Frankham, P.C., et al. Accelerated satiation after duodenal switch. (2005) Surg Obes Relat Dis 1(4): 408-412. PubMed | CrossRef | Others

4. Madsbad, S., Holst, J.J. GLP-1 as a mediator in the remission of type 2 diabetes after gastric bypass and sleeve gastrectomy surgery. (2014) Diabetes 63(10): 3172-3174. PubMed | CrossRef | Others

5. Evans, S., Pamuklar, Z., Rosko, J., et al. Gastric bypass surgery restores meal stimulation of the anorexigenic gut hormones glucagon-like peptide-1 and peptide YY independently of caloric restriction. (2012) Surg Endosc 26(4):1086-1094.

PubMed | CrossRef | Others

6. Vidal, J., Jimenez, A. Diabetes remission following metabolic surgery: is GLP-1 the culprit? (2013) Curr Atheroscler Rep 15(10): 357.

PubMed | CrossRef | Others

7. Karamanakos, S.N., Vagenas, K., Kalfarentzos, F., et al. Weight loss, appetite suppression, and changes in fasting and postprandial ghrelin and peptide-YY levels after Rouxen-Y gastric bypass and sleeve gastrectomy: a prospective, double blind study. (2008) Ann Surg 247(3): 401-407.

PubMed | CrossRef | Others

8. Fezzi, M., Kolotkin, R.L., Nedelcu, M., et al. Improvement in quality of life after laparoscopic sleeve gastrectomy. (2011) Obes Surg 21(8): 1161-1167. PubMed | CrossRef | Others

9. Márquez, M.F., Ayza, M.F., Lozano, R.B., et al. Gastric leak after laparoscopic sleeve gastrectomy. (2010) Obes Surg 20(9): 1306-1311.

PubMed | CrossRef | Others 
Citation: Botaitis, S., et al. Prevention and Management of Staple Line Leaks after Laparoscopic Sleeve Gastrectomy. (2018) J Anesth Surg 5(1): 95- 102.

10. Nedelcu, M., Noel, P., Gagner, M. Does the Surgeon's Experience Interfere with the Leak Rate After Laparoscopic Sleeve Gastrectomy? (2015) Bariatric Times 12(4 Suppl A): A7-A9.

PubMed $\mid$ CrossRef $\mid$ Others

11. Fuks, D., Verhaeghe, P., Brehant, O., et al. Results of laparoscopic sleeve gastrectomy: a prospective study in $135 \mathrm{pa}-$ tients with morbid obesity. (2009) Surgery 145(1): 106-113. PubMed |CrossRef $\mid$ Others

12. Gagner, M., Buchwald, J.N. Comparison of laparoscopic sleeve gastrectomy leak rates in four staple-line reinforcement options: a systematic review. (2014) Surg Obes Relat Dis 10(4):713-723.

PubMed |CrossRef $\mid$ Others

13. Bruce, J., Krukowski, Z.H., Al-Khairy, G., et al. Systematic review of the definition and measurement of anastomotic leak after gastrointestinal surgery. (2001) Br J Surg 88(9): 1157-1168. PubMed | CrossRef | Others

14. Csendes, A., Burdiles, P., Burgos, A.M., et al. Conservative management of anastomotic leaks after 557 open gastric bypasses. (2005) Obes Surg 15(9): 1252-1256.

PubMed | CrossRef | Others

15. Welsch, T., von Frankenberg, M., Schmidt, J., et al. Diagnosis and definition of anastomotic leakage from the surgeon's perspective. (2011) Chirurg 82(1): 48-55.

PubMed $\mid$ CrossRef $\mid$ Others

16. Mui, W.L., Ng, E.K., Tsung, B.Y., et al. Laparoscopic sleeve gastrectomy in ethnic obese Chinese. (2008) Obes Surg 18(12): 1571-1574.

PubMed | CrossRef $\mid$ Others

17. Burgos, A.M., Braghetto, I., Csendes, A., et al. Gastric leak after laparoscopic-sleeve gastrectomy for obesity. (2009) Obes Surg 19(12): 1672-1677.

PubMed | CrossRef | Others

18. Csendes, A., Braghetto, I., León, P., et al. Management of leaks after laparoscopic sleeve gastrectomy in patients with obesity. (2010) J Gastrointest Surg 14(9): 1343-1348. PubMed | CrossRef | Others

19. Ser, K.H., Lee, W.J., Lee, Y.C., et al. Experience in laparoscopic sleeve gastrectomy for morbidly obese Taiwanese: staple-line reinforcement is important for preventing leakage. (2010) Surg Endosc 24(9): 2253-2259.

PubMed | CrossRef | Others

20. Lacy, A., Ibarzabal, A., Pando, E., et al. Revisional surgery after sleeve gastrectomy. (2010) Surg Laparosc Endosc Percutan Tech 20(5): 351-356.

PubMed |CrossRef $\mid$ Others
21. Jurowich, C., Thalheimer, A., Seyfried, F., et al. Gastric leakage after sleeve gastrectomy-clinical presentation and therapeutic options. (2011) Langenbecks Arch Surg 396(7): 981-987.

PubMed | CrossRef | Others

22. Sakran, N., Goitein, D., Raziel, A., et al. Gastric leaks after sleeve gastrectomy: a multicenter experience with 2,834 patients. (2013) Surg Endosc 27(1): 240-245.

PubMed | CrossRef | Others

23. Moon, R.C., Shah, N., Teixeira, A.F., et al. Management of staple line leaks following sleeve gastrectomy. (2015) Surg Obes Relat Dis 11(1): 54-59.

PubMed | CrossRef | Others

24. Baker, R.S., Foote, J., Kemmeter, P., et al. The science of stapling and leaks. (2004) Obes Surg 14(10):1290-1298. PubMed | CrossRef | Others

25. Yehoshua, R.T., Eidelman, L.A., Stein, M., et al. Laparoscopic sleeve gastrectomy-volume and pressure assessment. (2008) Obes Surg 18(9): 1083-1088.

PubMed | CrossRef | Others

26. Abdelgawad, M., De Angelis, F., Iossa, A., et al. Management of complications and outcomes after revisional bariatric surgery: 3-year experience at a bariatric center of excellence. (2016) Obes Surg 26(9): 2144-2149.

PubMed | CrossRef | Others

27. Benedix, F., Benedix, D.D., Knoll, C., et al. Obesity Surgery Working Group. Are there risk factors that increase the rate of staple line leakage in patients undergoing primary sleeve gastrectomy for morbid obesity? (2014) Obes Surg 24(10):1610-1616.

PubMed | CrossRef | Others

28. Ali, M.R., Tichansky, D.S., Kothari, S.N., et al. Validation that a 1-year fellowship in minimally invasive and bariatric surgery can eliminate the learning curve for laparoscopic gastric bypass. (2010) Surg Endosc 24(1): 138-144. PubMed | CrossRef | Others

29. Geubbels, N., de Brauw, L.M., Acherman, Y.I., et al. The preceding surgeon factor in bariatric surgery: a positive influence on the learning curve of subsequent surgeons. (2014) Obes Surg 25(8): 1417-1424.

PubMed | CrossRef $\mid$ Others

30. Rosenthal, R.J., Diaz, A.A., Arvidsson, D., et al. International Sleeve Gastrectomy Expert Panel Consensus Statement: best practice guidelines based on experience of $>$ 12,000 cases. (2012) Surg Obes Relat Dis 8(1): 8-19. PubMed | CrossRef | Others

31. Baltasar, A., Serra, C., Pérez, N., et al. Laparoscopic sleeve gastrectomy: a multi-purpose bariatric operation. (2005) 
Obes Surg 15(8): 1124-1128.

PubMed | CrossRef | Others

32. Angrisani, L., Lorenzo, M., Borrelli, V., et al. The use of bovine pericardial strips on linear stapler to reduce extraluminal bleeding during laparoscopic gastric bypass: prospective randomized clinical trial. (2004) Obes Surg 14(9): 1198-1202. PubMed | CrossRef | Others

33. Himpens, J., Dobbeleir, J., Peeters, G. Long-term results of laparoscopic sleeve gastrectomy for obesity. (2010) Ann Surg 252(2): 319-324. PubMed | CrossRef | Others

34. Daskalakis, M., Berdan, Y., Theodoridou, S., et al. Impact of surgeon experience and buttress material on postoperative complications after laparoscopic sleeve gastrectomy. (2011) Surg Endosc 25(1): 88-97.

PubMed | CrossRef | Others

35. Stamou, K.M., Menenakos, E., Dardamanis, D., et al. Prospective comparative study of the efficacy of staple-line reinforcement in laparoscopic sleeve gastrectomy. (2011) Surg Endosc 25(11): 3526-3530.

PubMed |CrossRef | Others

36. Consten, E.C., Gagner, M., Pomp, A., et al. Decreased bleeding after laparoscopic sleeve gastrectomy with or without duodenal switch for morbid obesity using a stapled buttressed absorbable polymer membrane. (2004) Obes Surg 14(10): 1360-1366.

PubMed | CrossRef | Others

37. Sapala, J.A., Wood, M.H., Schuhknecht, M.P. Anastomotic leak prophylaxis using a vapor-heated fibrin sealant: report on 738 gastric bypass patients. (2004) Obes Surg 14(1): $35-42$.

PubMed | CrossRef | Others

38. Liu, C.D., Glantz, G.J., Livingston, E.H. Fibrin glue as a sealant for high-risk anastomosis in surgery for morbid obesity. (2003) Obes Surg 13(1): 45-48.

PubMed | CrossRef | Others

39. Ahmad Y.I. Abd El-Dayem, Mohammad E. El-Qousy, Khalifa, I., et al. The Incidence of Leak Following Laparoscopic Sleeve Gastrectomy with Pyloric Balloon Dilatation. (2015) Med J Cairo Univ 83(2): 99-102.

PubMed | CrossRef | Others

40. Nguyen, N.T. Tissue Perfusion in Sleeve Gastrectomy. (2015) Bariatric Times 12(4 Suppl A): A10-A11. PubMed | CrossRef | Others

41. Shimizu, H., Annaberdyev, S., Motamarry, I., et al. Revisional bariatric surgery for unsuccessful weight loss and complications. (2013) Obes Surg 23(11): 1766-1773.
PubMed |CrossRef | Others

42. Acholonu, E., McBean, E., Court, I., et al. Safety and shortterm outcomes of laparoscopic sleeve gastrectomy as a revisional approach for failed laparoscopic adjustable gastric banding in the treatment of morbid obesity. (2009) Obes Surg 19(12): 1612-1616.

PubMed |CrossRef | Others

43. Ramalingam, G., Anton, C.K. Our 1-year experience in laparoscopic sleeve gastrectomy. (2011) Obes Surg 21(12): 1828-1833.

PubMed |CrossRef | Others

44. Gonzalez, R., Nelson, L., Gallagher, S., et al. Anastomotic leaks after laparoscopic gastric bypass. (2004) Obes Surg 14:1299-1307.

PubMed | CrossRef | Others

45. Carucci, L.R., Conklin, R.C., Turner, M.A. Roux-en-Y gastric bypass surgery for morbid obesity: evaluation of leak into excluded stomach with upper gastrointestinal examination. (2008) Radiology 248(2): 504-510.

PubMed | CrossRef| Others

46. Angrisani, L., Cutolo, P.P., Buchwald, J.N., et al. Laparoscopic reinforced sleeve gastrectomy: early results and complications. (2011) Obes Surg 21(6): 783-793.

PubMed |CrossRef| Others

47. Glaysher, M., Khan, O.A., Mabvuure, N.T., et al. Staple line reinforcement during laparoscopic sleeve gastrectomy: does it affect clinical outcomes? (2013) Int J Surg 11(4): 286-289.

PubMed | CrossRef | Others

48. Parikh, M., Issa, R., McCrillis, A., et al. Surgical strategies that may decrease leak after laparoscopic sleeve gastrectomy: a systematic review and meta-analysis of 9991 cases. (2013) Ann Surg 257(2): 231-237.

PubMed | CrossRef | Others

49. Ballesta, C., Berindoague, R., Cabrera, M., et al. Management of anastomotic leaks after laparoscopic Roux-en Y-bypass. (2008) Obes Surg 18(6): 623-630.

PubMed |CrossRef | Others

50. Jinxing, Y., Turner, M.A., Cho, S.R., et al. Normal anatomy and complications after gastric bypass surgery: helical CT findings. (2004) Radiology 231(3): 753-760.

PubMed |CrossRef| Others

51. Wahby, M., Salama, A.F., Elezaby, A.F., et al. Is routine postoperative gastrografin study needed after laparoscopic sleeve gastrectomy? Experience of 712 cases. (2013) Obes Surg 23(11): 1711-1717.

PubMed |CrossRef | Others 
52. Nguyen, N.T., Nguyen, X.M., Dholakia, C. The use of endoscopic stent in management of leaks after sleeve gastrectomy. (2010) Obes Surg 20(9): 1289-1292.

PubMed |CrossRef | Others

53. Mennigen, R., Colombo-Benkmann, M., Senninger, N., et al. Endoscopic closure of postoperative gastrointestinal leakages and fistulas with the Over-the-Scope Clip (OTSC). (2013) J Gastrointest Surg 17(6): 1058-1065.

PubMed | CrossRef| Others

54. Goitein, D., Goitein, O., Feigin, A., et al. Sleeve gastrectomy: radiologic patterns after surgery. (2009) Surg Endosc 23(7): 1559-1563.

PubMed | CrossRef| Others

55. Campos, J.M., Pereira, E.F., Evangelista, L.F., et al. Gastrobronchial fistula after sleeve gastrectomy and gastric bypass: Endoscopic management and prevention. (2011) Obes Surg 21(10): 1520-1529. PubMed |CrossRef | Others

56. Fukumoto, R., Orlina, J., McGinty, J., et al. Use of Polyflexstents in treatment of acute esophageal and gastric leaks after bariatric surgery. (2007) Surg Obes Relat Dis 3(1): 68-71.

PubMed | CrossRef| Others

57. Bège, T., Emungania, O., Vitton, V., et al. An endoscopic strategy for management of anastomotic complications from bariatric surgery: a prospective study. (2011) Gastrointest Endosc 73(2): 238-244.

PubMed |CrossRef | Others

58. Baltasar, A., Serra, C., Bengochea, M., et al. Use of Roux limb as remedial surgery for sleeve gastrectomy fistulas. (2008) Surg Obes Relat Dis 4(6): 759-763.

PubMed | CrossRef | Others

Submit your manuscript to Ommega Publishers and we will help you at every step:

- We accept pre-submission inquiries

- Our selector tool helps you to find the most relevant journal

- We provide round the clock customer support

- Convenient online submission

- Thorough peer review

- Inclusion in all major indexing services

- Maximum visibility for your research

Submit your manuscript at

https://www.ommegaonline.org/submit-manuscript 